\title{
Studi Kinetika terhadap Rebusan Daun Alpukat Untuk Menghilangkan Sakit Kepala
}

\author{
Pratiwi Azizzah*1 \\ ${ }^{1}$ Pendidikan Kimia, FMIPA, Universitas Negeri Padang, Indonesia \\ *E-mail : pratiwiazizzah21@gmail.com
}

\begin{abstract}
Abstrak. Studi ini bertujuan untuk membuat rebusan daun alpukat untuk menghilangkan sakit kepala.Metode yang dilakukan adalah eksperimen dan uji aktifitas katalitik secara langsung.Tahapan pertama dilakukan dengan pembuatan rebusan dari daun alpukat.Uji aktifitas langsung dilakukan dengan variasi 1 kali selama 1 hari,Hasil eksperimen membuktikan bahwa rebusan daun alpukat dapat menghilangkan sakit kepala.Kondisi optimum ekstrak tercapai pada 1 kali dalam sehari selama 1 hari.Penyembuhan ini diduga karena aktifitas katalitik rebusan daun alpukat terhadap zat aktif

Keywords: Daun alpukat,antioksidan,kalium,vitamin, querstin, aktifitas katalitik
\end{abstract}

\section{Pendahuluan}

Reaksi kimia ${ }^{[1-3]}$ sangat penting bagi kehidupan manusia.Dimana pada reaksi kimia terjadi berbagai macam perubahan ${ }^{[4-6]}$ seperti perubahan suhu,perubahan warna, perubahan bau,adanya endapan dan adanya gelembung gas.Dimana perubahan ini akan mampu menandakan berbagai perubahan yang terjadi selama reaksi berlangsung ${ }^{[7-10]}$.Dimana nantinya dengan adanya perubahan reaksi ini kita dapat menentukan apakah suatu reaksi ini berjalan secara spontan atau tidak spontan ${ }^{[11-13]}$.Dalam percobaan ini kita perlu memperhatikan katalis ${ }^{[14-}$ ${ }^{17]}$ yang juga mempunyai syarat dan juga reaksi yang terjadi selama eksperimen sehingga nantinya kita dapat membuat suatu kesimpulan yang benar terhadap eksperimen yang dilakukan ${ }^{[18-19]}$.

Dalam suatu reaksi kimia ini kita dapat mengetahui laju reaksinya ${ }^{\text {[20- }}$ ${ }^{22]}$. Dimana yang dimaksud laju reaksi disini adalah kita dapat mengamati seberapa lama waktu yang dibutuhkan untuk suatu reaksi kimia itu berjalan ${ }^{[23-26]}$.Sehingga kita bisa mendapatkan data yang lebih akurat untuk menyimpulkan suatu eksperimen yang dilakukan ${ }^{[27-28]}$.Laju reaksi dalam suatu proses reaksi kimia ini sangat menentukan keakuratan data yang natinya akan kita publiskan sehingga kita memang harus benar-benar memperhatikan laju reaksi terhadap reaksi yang berlangsung ${ }^{[29-33]}$.

Reaksi kimia ${ }^{[34-36]}$ dapat dipercepat dengan adanya katalis.Katalis ${ }^{[37-40]}$ merupakan zat yang berguna untuk mempercepat laju reaksi tetapi zat tersebut tidak ikut bereaksi.Salah satu contoh dari katalis yaitu : $\mathrm{H}_{2} \mathrm{SO}_{4}, \mathrm{TiO}_{2}, \mathrm{dll}^{[41-44]}$. Dimana pada proses katalis ini ada 3 komponen yang harus diperhatiakan yaitu : komponen 
support ( Menyediakan tempat ), komponen active ( Untuk mendorong terjadinya reaksi), dan komponen promotor (komponen yang mengarahkan ${ }^{[45-49]}$.

Salah satu yang digunakan untuk mengakatalisis suatu reaksi kimia adalah enzim ${ }^{[50-53]}$. Dimana enzim adalah suatu biokatalis ${ }^{[54-56]}$. Didalam materi kimia fisika 2 juga dipelajari tentang macam-macam katalis disana dijelaskan katalis dapat dibagi menjadi 3 bagian yaitu katalis homogeny,katalis heterogen dan juga katalis enzim $^{[57-61]}$.

Daun alpukat memiliki metabolit sekunder flavonoid ${ }^{[62-66]}$.Daun alpukat merupakan tanaman yang sangat banyak tumbuh di Indonesia ${ }^{[67-70]}$,Daun alpukat ini sangat mudah ditemukan ${ }^{[71-72]}$,dimana daun alpukat banyak dijadikan sebagai obat herbal ${ }^{[73-75]}$,dimana daun alpukat dapat menyembuhkan berbagai macam penyakit diantaranya dapat menghilangkan sakit kepala.pada daun alpukat tidak haya mengandung flavonoid tetapi juga terdapat alkaloid ${ }^{[76-80]}$.

Menurut nenek atau orang tua yang tinggal di daerah Koto Berapak,Kabupaten Pesisir selatan daun alpukat ini memiliki banyak khasiat yang dapat menghilangkan berbagai macam penyakit ${ }^{[81-83]}$.Diantaranya daun alpukat ini diperkirakan dapat mengilangkan sakit kepala dan nyeri pada pinggang ${ }^{[84-}$ ${ }^{86]}$,bahkan untuk menurun kan tekanan darah.Menurut informasi yang saya peroleh daun alpukat ini dapat menghilangkan sakit kepala dengan cara merebus beberapa helai daun alpukat ${ }^{[87-90]}$.

Bedasarkan informasi yang diperoleh mengenai adsorbsi rebusan dari daun alpukat yang dipercaya dapat mengilangkan sakit kepala.Hal inilah yang membuat saya ingin membuktikan mengenai kepercayaan masyarakat Koto Berapak.Dimana tujuan dari penelitian ini adalah untuk membuktikan apakah rebusan daun alpukat dapat menghilangkan sakit kepala ${ }^{[91-93]}$.

\section{Metode}

\section{Alat dan Bahan}

Peralatan yang digunakan adalah Pisau (Gorme),Kamera (Oppo A37), Kompor gas (Rinai),Panci (Maspion), Gelas kaca (Kode HS9).Bahan yang digunakan adalah daun alpukat yang diambil dari halaman rumah di kenagarian Koto Berapak,air mineral ( Aqua ).

\section{Prosedur Kerja \\ Penyiapan Sampel}

Sampel diambil di Koto Anyi,Nagari Koto Berapak, Kecamatan Bayang,Kabupaten Pesisir Selatan.Sampel diambil sebanyak 5 lembar kemudian di cuci sampai bersih.

\section{Pembuatan Air Rebusan}

Menyiapkan 5 helai daun alpukat kemudin direbus kedalam panci yang berisi $500 \mathrm{~mL}$ air dan dipanaskan dengan kompor gas. Setelah mendidih matikan kompor dan rebusan daun alpukat tadi dituangkan kedalam gelas.Hasil yang rebusan daun alpukat yang diperoleh adalah $200 \mathrm{~mL}$.

\section{Pengujian Air Rebusan}


Hasil rebusan tadi diminum oleh penderita yang mengalami sakit kepala sebanyak $200 \mathrm{~mL}$ dan menanyakan kepada penderita terhadap perubahan yang terjadi setelah beberapa 1 jam penderita tersebut meminumnya ${ }^{[94-97]}$.

Metode yang dilakukan ini dapat dibuat secara diagram seperti berikut :

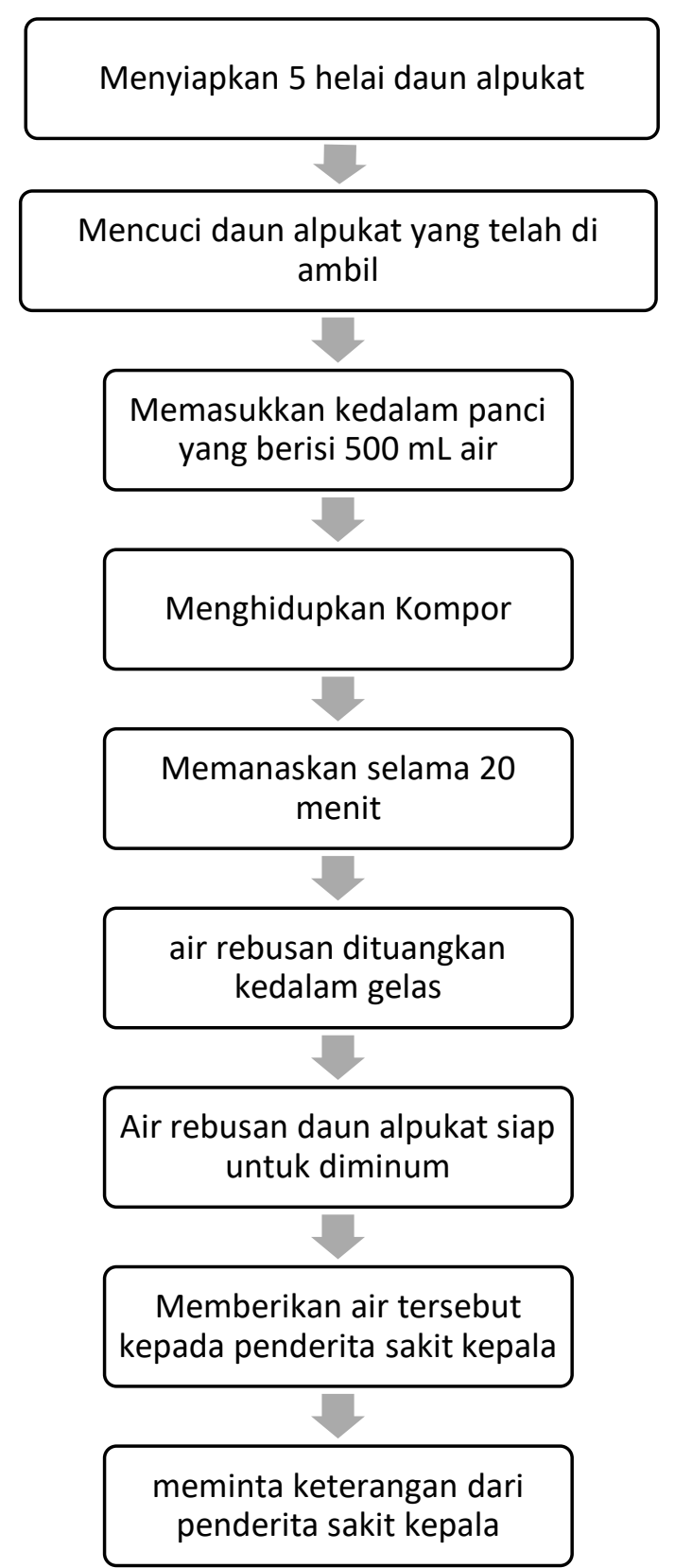

\section{Hasil dan Pembahasan}

\section{Hasil}

Hasil pembuatan rebusan daun alpukat dari $500 \mathrm{~mL}$ air diperoleh rebusan air sebanyak $200 \mathrm{~mL}^{(98)}$.Hal ini dapat dilihat pada gambar dibawah ini : 


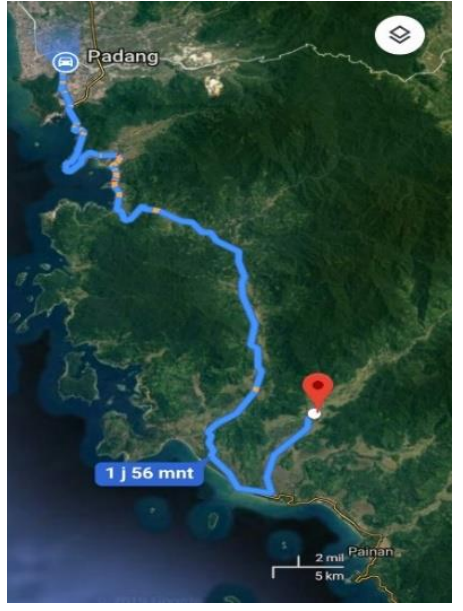

(a)

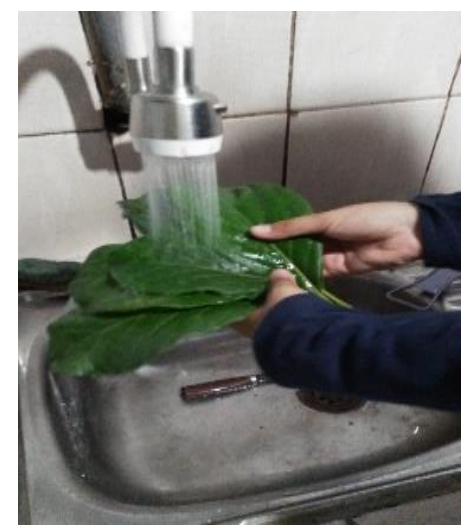

(d)

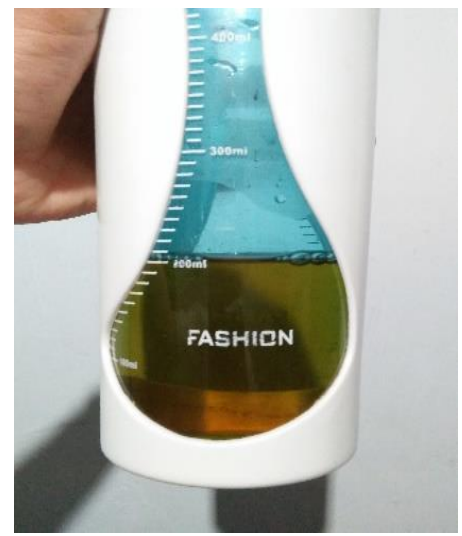

$(\mathrm{g})$

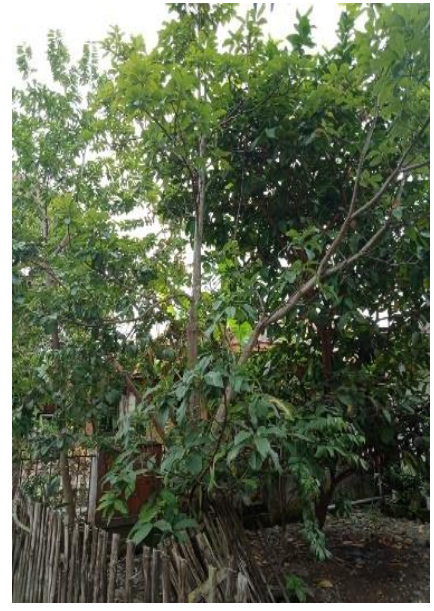

(b)

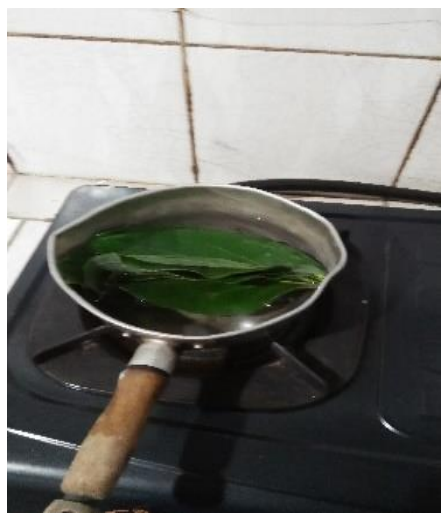

(e)

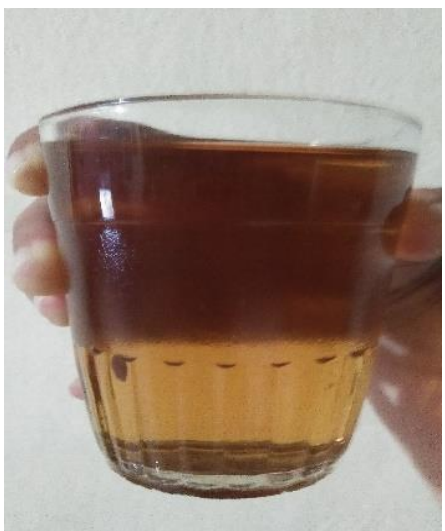

(h)

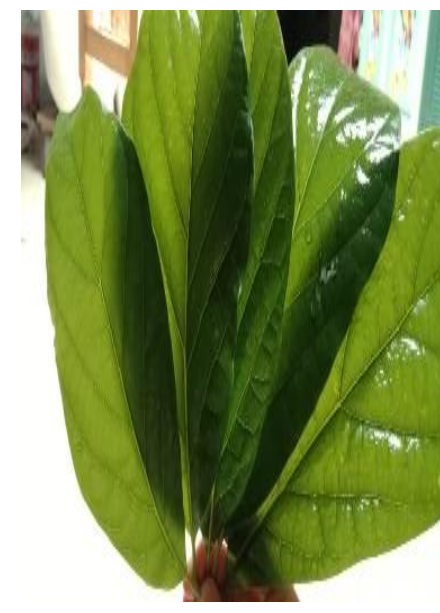

(c)

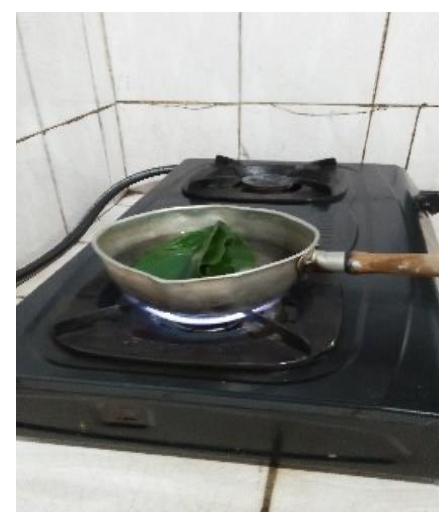

(f)

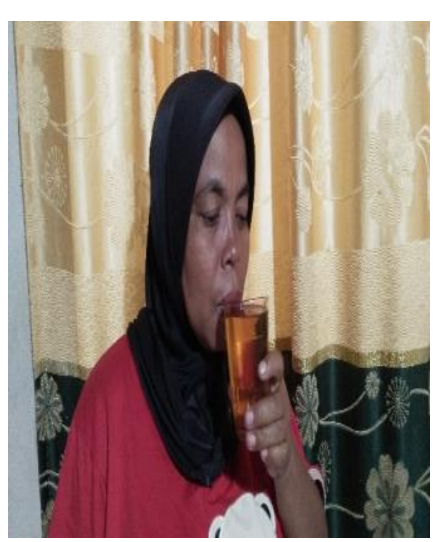

(i)

Gambar 1. Lokasi pengambilan sampel (a).Pohon daun alpukat (b).Daun alpukat yang sudah dipetik (c).Pencucian sampel (d).Persiapan perebusan sampel (e).Perebusan daun alpukat (f).Pengukuran hasil rebusan (g).Rebusan dari daun alpukat (h).Pengujian rebusan daun alpukat terhadap ibu yang mengalami sakit kepala (i). 


\section{Hasil Uji Coba}

Pengujian ini dilakukan kepada penderita sakit kepala,ternyata 1 gelas rebusan daun alpukat ini berhasil menghilangkan sakit kepala ${ }^{[99-101]}$.Sesuai dengan tabel berikut :

Tabel 1 : Hasil Uji Coba Rebusan Daun Alpukat

\begin{tabular}{lcc}
\hline NO & WAKTU & KETERANGAN \\
\hline 1 & 20 & $*$ \\
2 & 40 & $* *$ \\
3 & 60 & $* * *$ \\
\hline
\end{tabular}

Keterangan :

- $*$ = Masih terasa sakit

- $* *=$ Rasa sakit mulai menghilang

- $\quad * * *=$ Rasa Sakit kepala hilang

\section{PEMBAHASAN}

1. Pembuatan

Dalam melakukan pembuktian terhadap pengujian air hasil rebusan daun alpukat ${ }^{[102-105]}$ yang digunakan sebagai obat tradisional untuk menghilangkan rasa sakit kepala terdapat kendala dalam mencari seseorang yang sedang mengalami sakit kepala ${ }^{[106]}$. Sedangkan pada proses pencarian daun alpukat saya tidak mengalami kendala yang berarti karena pohon alpukat sendiri ada dihalaman rumah saya di kenegarian Koto Berapak,Kecamatan Bayang,Kabupaten Pesisir Selatan ${ }^{[107]}$.

Dalam pembuatan rebusan ini sama halnya dengan pembuatan ekstrak $^{[108-111]}$ Dimana pada proses pembutan atau perebusan daun alpukat ini dapat dipengaruhi oleh 2 faktor yaitu factor suhu dan juga faktor waktu.Faktor ssuhu sangat mempengaruhi dalam pembuatan rebusan ini untuk mendapatkan rebusan yang baik kita harus menjaga suhu agar terus tetap atau konstan ${ }^{[12-}$ ${ }^{113]}$.Sedangkan faktor waktu ini dapat menentukan tingkat dari hasil rebusan yang diperoleh semakin lama perbusan maka zat yang terkandung dalam daun alpukat akan semakin larut dalam air sehingga kita memperoleh hasil yang bagus $^{[114-115]}$.

2. Pembahasan Uji Coba 


\section{Grafik 1.Pengaruh Rebusan Daun Alpukat terhadap Penghilangan Sakit Kepala}

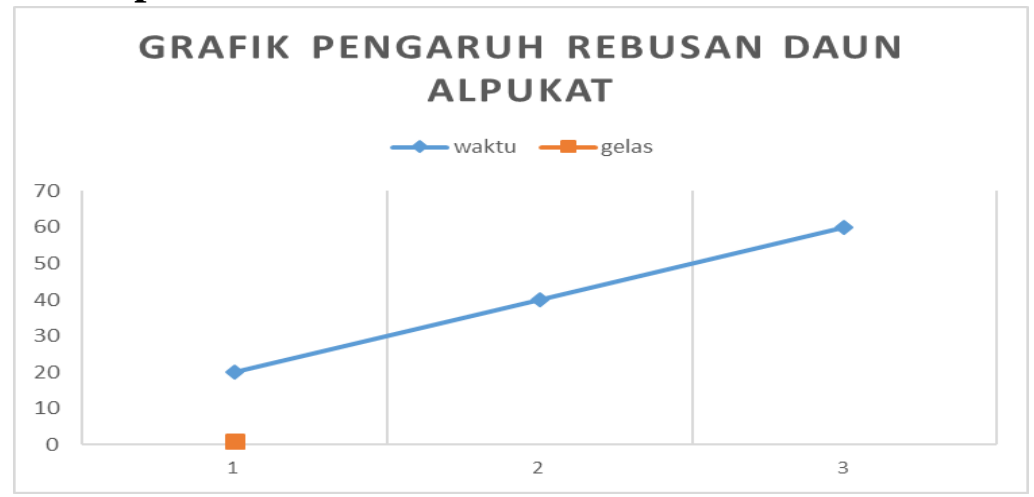

Pada gambar diatas terlihat grafik dari pengaruh rebusan dari daun alpukat untuk menghilangkan sakit kepala terus meningkat.Hal ini dikarenakan semakin lama waktu setelah meminum air rebusan daun alpukat akan semakin menghilangkan rasa sakit kepala yang di rasakan,air rebusan dari daun alpukat ini membutuhkan waktu untuk bereaksi didalam tubuh manusia.Pada grafik rasa sakit kepala dapat hilang setelah meminum rebusan daun alpukat setelah 1 jam $^{[115-118]}$.

\section{Interaksi}

Rebusan daun alpukat ini diyakini dapat menghilangkan sakit kepala dikarenakan zat aktif yang terdapat didalam daun alpukat tersebut [119${ }^{122]}$ Daun alpukat memiliki kandungan antioksidan,vitamin dan kalium ${ }^{[123-}$ ${ }^{127]}$.Jika tubuh sesorang kekurangan kalium,maka orang tersebut akan mudah merasakan sakit kepala ${ }^{[128-132]}$.Karena daun alpukat memiliki kandungan kalium yang baik sebab itulah daun alpukat ini dapat menghilangkan sakit kepala atau rasa nyeri dikepala ${ }^{[133-135]}$.

Menurut masyarakat sekitar ekstrak dari rebusan daun alpukat ini tidak hanya digunakan untuk menghilangkan rasa sakit kepala,tetapi juga dapat menghilangkan rasa nyeri pada pinggang dan menurunkan tekana darah dengan meminum ekstrak dari daun alpukat ${ }^{[136-138]}$.

Tanaman alpukat ${ }^{[139-140]}$ merupakan tanaman yang mengandung banyak manfaatnya digunakan sebagai tanaman herbal,yang memiliki cabang yang bnayak di setiap rantingnya dan memiliki bentuk daun yang lebar dan mempunyai bentuk buah yang bulat atau berbentuk bundar dan pada pengujian didapatkan ekstrak dari tanaman alpukat ini memiliki warna hijau kecokelatan ${ }^{[141]}$.

Dalam daun alpukat tidak hanya mengandung zat aktif seperti antioksidan,kalium dan vitamin tetapi daun alpukat juga memiliki kandungan zat querstin, diamna zat querstin ini diyakinin dapat melindungi tubuh manusia dari rasa nyeri baik itu nyeri pada pinggang ataupun nyeri di kepala tidak hanya itu zat querstin ini juga dapat menghambat pertumbuhan bakteri $^{[142-145]}$.

Dalam daun alpukat sebenarnya mengandung senyawa antioksidan dan zat bioaktif ${ }^{[146]}$.Salah satu contohnya adalah fenolik.Dimana 
komponen-komponen inilah yang membuat alpukat banyak digunakan sebagai obat tradisonal ${ }^{[147]}$.

Ternyata pada daun alpukat tidak hanya dapat digunakan untuk menghilangkan rasa sakit kepala,tetapi rebusab daun alpukat juga dapat digunakan untuk menurunkan tekanan darah dan mengurangi resiko kanker ${ }^{[148-149]}$.Selain daunnuya daging alpukat juga dapat diguanakn untuk perawatan muka dimana daging alpukat ini dijadikan masker untuk mengurangi penuan pada kulit ${ }^{[150]}$.

\section{KESIMPULAN}

1. Ekstrak dari rebusan daun alpukat yang diperoleh dari 5 helai daun yang dimasukkan kedalam $500 \mathrm{~mL}$ air adalah sebanyak $200 \mathrm{~mL}$.

2. Ekstrak dari rebusan daun alpukat ini dapat menghilangkan sakit kepala setelah pemakaian 1 kali sehari sebanyak $200 \mathrm{~mL}$ dalam waktu 1 jam.

3. Ekstrak dari rebusan daun alpukat dapat menyembuhkan sakit kepala karena diduga daun alpukat memilikikandungan antioksidan,vitamin dan kalium yang sangat baik.

\section{REFERENSI}

[1] Luh Joni Erawati Dewi.2009. Pengenmbangan Media Pembelajaran Reaksi Kesetimbangan Kimia. Vol 6, No 2

[2] Febriani, S. S., Yolanda, T., Arianti, V. A., \& Zainul, R. (2018, October 12). A Review Solid Stated : Principles and Methode. https://doi.org/10.31227/osf.io/7us4x

[3] Tri Windarti,Ahmad Suseno.2004. Preparasi Katalis Zeolit Alam Asam Sebagai Katalis Dalam Proses Pirolisis Katalitik Polietilena. Vol. VII No.3

[4] Chatarina Wariyah,Chairil Anwar,Mary Astuti, dan Supriyadi.2007. Kinetika Penyerapan Air Pada Beras (Kinetics of Water Absorption in Rice). Vol. 27, No. 3

[5] Prayitno. 2007.Kajian Kinetika Kimia Model Matematik Reduksi Kadmium Melalui Laju Reaksi,Konstanta dan Orde Reaksi Dalam Proses Elektrokimia . Vol 10, No 1

[6] Liza, Y. M., Yasin, R. C., Maidani, S. S., \& Zainul, R. (2018, October 9). SOL GEL : PRINCIPLE AND TECHNIQUE (A REVIEW). https://doi.org/10.31227/osf.io/2cuh8

[7] Sanjaya, H. (2018) "DEGRADASI METIL VIOLET MENGGUNAKAN KATALIS ZnO-TiO2 SECARA FOTOSONOLISIS", EKSAKTA: Berkala Ilmiah Bidang MIPA, 19(1), pp. 91-99. doi: 10.24036/eksakta/vol19iss $1 / 131$.

[8] Zainul, R. (2018, August 16). Effect of Temperature and Particle Motion against the ability of $\mathrm{ZnO}$ Semiconductor Photocatalyst in Humic Acid. https://doi.org/10.31227/osf.io/wnygb 
[9] Sofiyanita, Zona Octaria.2018. Fenthion Compound Degradation in the Pesticide Bayleton 500 ec in Sonolysis, Ozonolysis and Sonozolysis with Addition of TiO2-anatase. Vol. 19 Issue 2.

[10] Zuhra,Husni Husin, Fikri Hasfita,Wahyu Rinaldi.2915. Preparasi Katalis Abu Kulit Kerang Untuk Transesterifikasi Minyak Nyamplung Menjadi Biodiesel. Vol. 35, No. 1

[11] Nilda Apriyati Tengo,Nurhayati Bialangi,Nita Suleman.2013. Isolasi dan Karakterisasi Senyawa Alkaloid dari Daun Alpukat (Persea Americana Mill).VOL 07. NO 01

[12] Wuri Marsigit, Mary Astuti, Sri Anggrahini, Sri Naruki. 2016. Kandungan Gizi, Rendemen Tepung dan Kadar Fenol Total Alpukat (Persea americana, Mill) Varietas Ijo Panjang dan Ijo Bundar. Vol. 36, No. 1

[13] H Parbuntari Y Prestica, R Gunawan, M N Nurman, F Adella. 2018. Preliminary Phytochemical Screening (Qualitative Analysis) of Cacao Leaves (Theobroma cacao L). Vol.19 Issue2. DOI :10.24036/eksakta/vol19iss $02 / 142$

[14] Azwir Anhar, Ramadhan Sumarmin and Rahadian Zainul.2016. Measurement of glycemic index of West Sumatera local rice genotypes for healthy food selection. Vol 8 No.8

[15] Nurfadilah, K. K., \& Zainul, R. (2019, February 3). Kalium Nitrat (KNO3): Karakteristik Senyawa dan Transpor Ion. https://doi.org/10.31227/osf.io/dr8ef

[16] M., Sanjaya, H., \& Zainul, R. (2018, August 11). Characterization of napa soil and adsorption of $\mathrm{Pb}$ (II) from aqueous solutions using on column method. https://doi.org/10.31227/osf.io/t8fh9

[17] Desy Kurniawati, Intan Lestari, Harmiwati, Salmariza Sy, Zulkarnain Chaidir, Edison Munaf, Rahmiana Zein, Hermansyah Aziz and Rahadian Zainul. 2015. Biosorption of Pb (II) from aqueous solutions using column method by lengkeng ( Euphoria logan lour) seed and shell. Vol 7 No.12

[18] Prabowo, H. (2018) "PENYELIDIKAN KELAYAKAN KIMIA DAN PENYEBARAN CADANGAN PASIR BESI DAERAH TIKU KABUPATEN AGAM UNTUK BAHAN BAKU SEMEN PADA PT. SEMEN PADANG”, EKSAKTA: Berkala Ilmiah Bidang MIPA, 19(1), pp. 39-42. doi: 10.24036/eksakta/vol19-iss1/121.

[19] I Wayan Rai Widarta, I Wayan Arnata. 2017. Ekstraksi Komponen Bioaktif Daun Alpukat dengan Bantuan Ultrasonik pada Berbagai Jenis dan Konsentrasi Pelarut. Vol. 37, No. 2. DOI: http://doi.org/10.22146/agritech.10397 ISSN 0216-0455 (Print), ISSN 25273825 (Online) Tersedia online di https://jurnal.ugm.ac.id/agritech/

[20] Sumarmin, R. (2018) "Pengaruh Ekstrak Kulit Buah Manggis (Garcinia mangostana L.) terhadap Histologis Pankreas Mencit (Mus musculus L. Swiss Webster) yang Diinduksi Sukrosa", EKSAKTA: Berkala Ilmiah Bidang MIPA, 19(1), pp. 100-112. doi: 10.24036/eksakta/vol19-iss1/123.

[21] Agnes Murdiati, Hastari Wuryastuti,Y. Marsono,Eni Harmayani.2009.Sorbitol-Oleat Poiester : Produksi,sifat fisikokimia dan Perubahannya Selama Penggorengan.Vol. 29, No. 2 
[22] R Zainul, A Alif, H Aziz, S Arief .2015. Disain Geometri Reaktor Fotosel Cahaya Ruang.Jurnal Kimia Riset.Vol 8 No. 2 DOI: https://doi.org/10.25077/jrk.v8i2.230

[23] Dinata, Agil A., Abel M. Rosyadi, Syukri Hamid, and Rahadian Zainul. 2018. "A Review CHEMICAL VAPOR DEPOSITION : PROCESS AND APPLICATION.” INA-Rxiv. October 15. doi:10.31227/osf.io/yfeau.

[24] Dewa Gede Katja,Edi Suryanto dan Frenly Wehantouw.2009. Potensi Daun Alpukat (Persea Americana Mill) Sebagai Sumber Antioksidan Alami. Vol. 2 No. 1

[25] Ummu Mukaromah,Sri Hetty Susetyorini,Siti Aminah.2010. Kadar Vitamin C,Mutu Fisik,pH dan Mutu Organoleptik Sirip Rosella (Hibiscus Sabdariffa, L) Bedasarkan Cara Ekstraksi. Vol. 01 No. 01

[26] Ietje Wientarsih, Rini Madyastuti, Bayu Febram Prasetyo, Anggara Aldobrata.2012.Anti Lithiasis Activity of Avocado (Persea americana Mill) Leaves Extract in White Male Rats.Vol.19 No. 1.Available online at: http://journal.ipb.ac.id/index.php/hayati DOI: 10.4308/hjb.19.1.49

[27] Chatri, M., Mansyurdin, M., Bakhtiar, A. and Adnadi, P. (2017) "PERBANDINGAN KOMPONEN MINYAK ATSIRI ANTARA DAUN MUDA DAN DAUN DEWASA PADA HYPTIS SUAVEOLENS (L.)POIT”, EKSAKTA: Berkala Ilmiah Bidang MIPA, 18(02), pp. 1-12. doi: 10.24036/eksakta/vol18-iss02/41.

[28] Saiya,A. (2017) “ANALISIS RESIDU KLORPIRIFOS DALAM SAYURAN KUBIS DENGAN METODE HPLC DI BEBERAPA PASAR TRADISIONAL DI SULAWESI UTARA", EKSAKTA: Berkala Ilmiah Bidang MIPA, 18(02), pp. 77-85. doi: 10.24036/eksakta/vol18-iss02/57.

[29] Zainul, R. (2018, August 16). Determination of the half-life and the quantum yield of $\mathrm{ZnO}$ semiconductor photocatalyst in humic acid. https://doi.org/10.31227/osf.io/e8a9x

[30] Evy Damayanthi,Lilik Kustiyah, Mahani Khalid, dan Henry Farizal.2010. Aktivitas Antioksidan Bekatul Lebih Tinggi Daripada Jus Tomat dan Penurunan Aktivitas Antioksidan Serum Setelah Intervensi Minuman Kaya Antioksidan.Vol.5 No.3.Hal : 205-210

[31] Endang Triwahyuni Maharani, Ana Hidayati Mukaromah, Jatmiko Susilo. 2012. Seminar Nasional Hasil Penelitian 2012 ; Analisis Kalium Dalam Air Teh Daun Sukun (Artocarpus altilis). ISBN : 978-602-18809-0-6

[32] Sari, A. (2017) "POTENSI ANTIOKSIDAN ALAMI PADA EKSTRAK DAUN JAMBLANG (Syzigium cumini (L.) Skeels)”, EKSAKTA: Berkala Ilmiah Bidang MIPA, 18(02), pp. 107-112. doi: 10.24036/eksakta/vol18iss02/61.

[33] Liberty P. Malangngia, Meiske S. Sangia, Jessy J. E. Paendong.2012.Penentuan Kandungan Tanin dan Uji Aktivitas Antioksidan Ekstrak Biji Buah Alpukat (Persea americana Mill.).Vol 01 No. 01

[34] Chusnul Hidayat, Supriyadi, Probondari. 2009.Pengembangan Zirkonia Agarosa Sebagai Matrik Untuk Biokatalis Pada Amobilitas Lipase Candida Rugosa. Vol. 29, No. 3

[35] Sanjaya, H. (2018) "DEGRADASI METIL VIOLET MENGGUNAKAN KATALIS ZnO-TiO2 SECARA FOTOSONOLISIS", EKSAKTA: Berkala 
Ilmiah Bidang MIPA, 19(1), pp. 91-99. doi: 10.24036/eksakta/vol19iss $1 / 131$.

[36] Zainul, R. (2018, August 16). Design and Modification of Copper Oxide Electrodes for Improving Conversion Coefficient Indoors Lights (PV-Cell) Photocells. https://doi.org/10.31227/osf.io/pgn84

[37] Zainul, R. (2018, August 16). Determination of the half-life and the quantum yield of $\mathrm{ZnO}$ semiconductor photocatalyst in humic acid. https://doi.org/10.31227/osf.io/e8a9x

[38] Liza, Y. M., Yasin, R. C., Maidani, S. S., \& Zainul, R. (2018, October 9). SOL GEL : PRINCIPLE AND TECHNIQUE (A REVIEW). https://doi.org/10.31227/osf.io/2cuh8

[39] Febriani, S. S., Yolanda, T., Arianti, V. A., \& Zainul, R. (2018, October 12). A Review Solid Stated : Principles and Methode. https://doi.org/10.31227/osf.io/7us4x

[40] Dinata, A. A., Rosyadi, A. M., Hamid, S., \& Zainul, R. (2018, October 15). A Review CHEMICAL VAPOR DEPOSITION : PROCESS AND APPLICATION. https://doi.org/10.31227/osf.io/yfeau

[41] Putri, D. F., Ritonga, H. M., Murdiati, V., \& Zainul, R. ( 2018, October 15). A REVIEW WHAT IS HYDROTHERMAL ?. https://doi.org/10.31227/osf.io/dm56c

[42] Lubis, A. P., \& Zainul, R. (2018, November 5). Interaksi Molekuler Amonium Hidroksida. https://doi.org/10.31227/osf.io/jht3b

[43] Husna,H., \& Zainul, R. (2019, February 3).A Review : Aspek Termodinamika LiNO3 dalam Larutannya.https://doi.org/10.31227/osf.io/45mbd

[44] Feronika, N. I., \& Zainul, R. (2018, November 19). Kalium Permanganat: Termodinamika Mengenai Transport Ionik dalam Air. https://doi.org/10.31227/osf.io/g6eyk

[45] Yanti, C. F., \& Zainul, R. (2018, December 2). A Review Ba (OH)2 : Transpor Ionik pada Barium Hidroksida di dalam Air dengan Konsep Termodinamika. https://doi.org/10.31227/osf.io/fsbq3

[46] Y., \& Zainul, R. (2018, November 18). SILVER SULFATE (Ag2SO4): MOLECULAR ANALYSIS AND ION TRANSPORT. https://doi.org/10.31227/osf.io/n8g9k

[47] Hakimi, A., \& Zainul, R. (2019, January 31). Asam Arsenat (H3AsO4) : Analisis Molekular dan Karakteristik Senyawa. https://doi.org/10.31227/osf.io/e486z

[48] Artika, P. I., \& Zainul, R. (2018, November 19). Potassium Bromide (KBr): Transformasi ionik dan sifat temodinamika dalam Larutan. https://doi.org/10.31227/osf.io/a5hyz

[49] Husna, A. D., \& Zainul, R. (2019, February 4). Analisis Molekular dan Karakteristik Hidrogen Sianida (HCN). https://doi.org/10.31227/osf.io/7xej9

[50] Kristy, D. P., \& Zainul, R. (2019, February 3). Analisis Molekular dan Transpor Ion Natrium Silikat. https://doi.org/10.31227/osf.io/8ac4m

[51] Delvi, I. P., \& Zainul, R. (2019, February 3). Mercury (II) Nitrate (Hg (NO3)2): Interaksi Molekul dan Adsorpsi $\mathrm{Hg}$ dengan Karbon Aktif. https://doi.org/10.31227/osf.io/eqyax

[52] Zainul, R., \& Prima, C. B. (2018, November 11). Desain Geometri Sel PV. https://doi.org/10.31227/osf.io/7n8t4 
[53] Alfionita, T., \& Zainul, R. (2019, January 29). Calcium Chloride (CaCl2) : Characteristics and Molecular Interaction in Solution. https://doi.org/10.31227/osf.io/m37xj

[54] Yuliani, F., \& Zainul, R. (2018, November 13). Analisis Termodinamika Molekul Magnesium Sulphate (MgSO4). https://doi.org/10.31227/osf.io/uxz4y

[55] H, Azhar, M, \& Zainul, R. (2018, September 19). THE EFFECTIVENESS OF STRUCTURED INQUIRY BASED MODULE TO IMPROVE MENTAL MODEL OF CONCEPT MOLE. https://doi.org/10.31227/osf.io/ckjtb

[56] Putri, G. A., H., \& Zainul, R. (2018, September 25). DEVELOPMENT OF PERIODIC TABLE INTERACTIVE INSTRUCTIONAL MULTIMEDIA IN CHEMISTRY LESSON FOR Xth GRADE SMA / MA. https://doi.org/10.31227/osf.io/2hsme

[57] Zainul, R., Alif, A., Aziz, H., Arief, S., \& s. (2018, August 16). Photoelectrosplitting Water Mechanism at Carbon Electrode Surface using Indoor lights. https://doi.org/10.31227/osf.io/vcxq8

[58] Chaidir, z., Zainul, R., Nurakhbari, D., \& Salim, M. (2018, July 29). Optimization of Spirulina Platensis Culture for Antioxidant Production. https://doi.org/10.17605/OSF.IO/FD6E4

[59] Chaidir, z., Fadjria, N., A., \& Zainul, R. (2018, August 11). ISOLATION AND MOLECULAR IDENTIFICATION OF FRESHWATER MICROALGAE IN MANINJAU LAKE WEST SUMATERA. https://doi.org/10.31227/osf.io/nbcuf

[60] Zainul R, Wardani S. The Hydrogen Generator Performance of Sandwich Designed 4/4 Al-Cu Plates. EKSAKTA [Internet]. 30Apr.2019 [cited 12May2019];20(1):1004.Available.from:http://eksakta.ppj.unp.ac.id/index.p hp/eksakta/article/view/177

[61] M., Sanjaya, H., \& Zainul, R. (2018, August 11). Characterization of napa soil and adsorption of $\mathrm{Pb}$ (II) from aqueous solutions using on column method. https://doi.org/10.31227/osf.io/t8fh9

[62] Y., \& Zainul, R. (2018, November 18). SILVER SULFATE (Ag2SO4): MOLECULAR ANALYSIS AND ION TRANSPORT. https://doi.org/10.31227/osf.io/n8g9k

[63] H.,Azhar, M.,\& Zainul, R. (2018, September 19). THE EFFECTIVENESS OF STRUCTURED INQUIRY BASED MODULE TO IMPROVE MENTAL MODEL OF CONCEPT MOLE. https://doi.org/10.31227/osf.io/ckjtb

[64] Zainul, R.,\& Prima, C. B. (2018, December 9). TEKNOLOGI MATERIAL MAJU Prinsip Dasar dan Aspek Rekayasa. https://doi.org/10.31227/osf.io/p63wc

[65] Dwynda, I., \& Zainul, R. (2018, November 19). Boric Acid (H3 (BO3): Recognize The Molecular Interactions in Solutions. https://doi.org/10.31227/osf.io/6wead

[67] Artika,P. I., \& Zainul, R. (2018, November 19). Potassium Bromide (KBr): Transformasi ionik dan sifat temodinamika dalam Larutan. https://doi.org/10.31227/osf.io/a5hyz 
[68] Sari, M., \& Zainul, R. (2018, November 19). Kalium Dikromat (K2Cr2O7) Spektroskopi dan Transpor K2Cr2O7. https://doi.org/10.31227/osf.io/w92je

[69] Yanti, C. F., \& Zainul, R. (2018, December 2). A Review Ba (OH)2 : Transpor Ionik pada Barium Hidroksida di dalam Air dengan Konsep Termodinamika. https://doi.org/10.31227/osf.io/fsbq3

[70] Putri, G. E., Arief, S., Jamarun, N., Gusti, F. R., \& Zainul, R. (2018, December 10). Microstuctural Analysis and Optical Properties of Nanocrystalline Cerium Oxides Synthesized by Precipitation Method. https://doi.org/10.31227/osf.io/qcz4y

[71] Tasim, Lina, Santoso, I R. S., Rombang, W A. R..2013.Analisis Pemahaman Konsep Reaksi Kimia Melalui Pendekatan Pembelajaran Langsung Pada Siswa SMP Negeri 13 Tidore Kepulauan Vol 1, No 3

[72] Sukardi, Sukardi.2001.Antioksidan Alami Sebagai Pengawet Makanan dan Pemeliharaan Kesehatan Tubuh Vol 2No 31

[73] Rizqa, Ifan.2010. PERANGKAT LUNAK PENYUSUNAN FORMULA HERBAL SEBAGAI MEDIA PELESTARIAN BUDAYA PENGOBATAN TRADISIONAL KHAS INDONESIA Vol 1, No 1

[74] Winata, Susanty D .2003. Cara Bijak Menggunakan Obat Herbal vol. 11 no. 29

[75] Lasarus,Agnesi.2013.UJI EFEK ANALGESIK EKSTRAK DAUN PEPAYA (Carica pepaya (L.)) PADA MENCIT (Mus musculus) Vol 1, No 2

[76] Faustina, Prapto Yudono, dan Rohmanti Rabaniyah, Ega .2012. Pengaruh Cara Pelepasan Aril dan Konsentrasi KNO3 Terhadap Pematahan Dormansi Benih Pepaya (Carica papaya L.) Vol 1, No 1

[77] Fotokatalitik dalam Mendegradasi Fenol dengan Katalisis $\mathrm{TiO} 2$ dengan Adanya Ion Logam Fe(III) dan Cu(II). Vol 1, No 1

[78] Altway, Ali, Winardi, Sugeng, Rachimoellah, M,2004.Aplikasi Packet Diffusion Model untuk Menganalisis Pengaruh Fenomena Micromixing terhadap Jalannya Reaksi Kimia Paralel di dalam Reaktor Tangki reraduk Kontinyu dengan Aliran Umpan Terpisah. Vol 28, No 2

[79] Nunung D.Putra, Khaswar Syamsu,Ani Suryani,2004. KAJIAN PENGARUH KONSENTRASI H2SO4 DAN SUHU REAKSI PADA PROSES PRODUKSI SURFAKTAN METIL ESTER SULFONAT (MES) DENGAN METODE SULFONASI.VOL 14,NO 2

[80] Irawan, RM. Bagus, 2006. PENGARUH KATALIS TEMBAGA DAN KROM TERHADAP EMISI GAS CARBON MONOKSIDA DAN HIDRO CARBON PADA KENDARAAN MOTOR BENSIN.Vol 4,No 1

[81] Suwondo, Syarif ( Unpad, Bandung ), Sidik, Sidik ( Unpad, Bandung ), S., Sumadilaga R. ( Unpad, Bandung ), Soelarko, R. M. ( Unpad, Bandung ). 2012. Aktivitas Antibakteri Daun Sirih (Piper Betle L.) Terhadap Bakteri Gingivitis Dan Bakteri Pembentuk Plak/Karies Gigi (Streptococcus Mutans). Warta Tumbuhan Obat Indonesia. Vol 1, No 1 Jan (1992)

[82] Arifulloh, Arifulloh, Oktavianawati, Ika, Adi Winata, I Nyoman.2016. EKSTRAKSI LIKOPEN DARI BUAH TOMAT (LYCOPERSICUM ESCULENTUM MILL.) DENGAN BERBAGAI KOMPOSISI PELARUT. Berskala sainstek. Vol.4 no.1

[83] Iswari, K.2015. Pemanfaatan Tomat dan Sirsak sebagai Bahan Dasar Pembuatan Produk Suplemen Kesehatan. Jurnal holtikultura. Vol.25 no.4 
[84] Megawati, Megawati , Sediawan, Wahyudi Budi,Sulistyo, Hary,Hidayat, Muslikhin.2009.kinetika reaksi hidrolisis. Reaktor. Vol.12 no.4

[85] Susanti, N. M. P., Dewi, L. P. M. K., Widjaja, I N.K., Wirasuta, I.M.A.G., Gityarani, K. G.2016. EKSTRAKSI LIKOPEN DARI LIMBAH BUAH TOMAT (Solanumlycopersicum L.). Jurnal farmasi udayana. Vol.5 no.1.

[86] Sari, Diana Permata, Purwarianti, Ayu.2014. EKSTRAKSI KATA KUNCI OTOMATIS UNTUK DOKUMEN BAHASA INDONESIA STUDI KASUS: ARTIKEL JURNAL ILMIAH KOLEKSI PDII LIPI. Jurnal dokumentasi dan informatika.vol.35 no.2

[87] DINIATIK, SOEMARDY, EDDY, INDRI, KHANINA. 2007. PERBANDINGAN KADAR FLAVONOID TOTAL DAN TANIN TOTAL PADA TEH HIJAU DAN TEH HITAM Camellia siniensis (L.) O.K. PHARMACY. Vol 5, No 3

[88] Kusnaryo, Radya Purna Wijaya, Ali Altway,. 2008. ANALISA TRANSFER MASSA DISERTAI REAKSI KIMIA PADA ABSORPSI CO2. Teknik Kimia. Vol 2, No 2

[89] Widodo, Prasetya, Agus. 2014. Modifikasi Sistem Destilasi Minyak Atsiri Daun Sirih (Piper Betle Linn) Dengan Penerapan Volume Air Rebusan Konstan. Asean Journal Of Systems Engineering. Vol 2, No 1 (2014)

[90] Malangngi, Liberty , Sangi, Meiske, Paendong, Jessy . 2012. Penentuan Kandungan Tanin dan Uji Aktivitas Antioksidan Ekstrak Biji Buah Alpukat (Persea americana Mill.). JURNAL MIPA UNSRAT ONLIN. Vol 1, No 1.

[91] Wardhani, Ratih Pramita, Ningsih, Rini Rahayu, Ramadhona, Rika, Astuti, Hutari Puji,Fitriyani, Noor,2013. TEH BIJI SEMANGKA (CITRULLUS LANATUS) SEBAGAI OBAT HERBAL ALTERNATIF JANTUNG DAN ANTI KANKER. Vol. 4, No.2

[92] Erawati Dewi,Luh Joni. 2009. Pengembangan Media Pembelajaran Reaksi Kesetimbangan Kimia. JPTK. Vol 6, No 2 (2009): Edisi Juli 2009

[93] Megawati, Megawati , Sediawan, Wahyudi Budi,Sulistyo, Hary,Hidayat, Muslikhin.2009.kinetika reaksi hidrolisis. Reaktor. Vol.12 no.4

[94] Susanti, N. M. P., Dewi, L. P. M. K., Widjaja, I N.K., Wirasuta, I.M.A.G., Gityarani, K. G.2016. EKSTRAKSI LIKOPEN DARI LIMBAH BUAH TOMAT (Solanumlycopersicum L.). Jurnal farmasi udayana. Vol.5 no.1.

[95] Lubis, Humairah Medina Liza. 2018. Kajian Molekuler P53 Pemanfaatan Tanaman Herbal Buah Legundi (Vitex Trifolia L) Terhadap Massa Tumor Jaringan Kulit. Buletin Farmatera. Vol 3, No 1 (2018)

[96] Darminto, . ( State University Of Makassar ), Muharram, .. 2009. Senyawa Alkoloid Dari Ekstrak Aseton Daun Sambung Nyawa Gynura Procumbens L. (Gpl). Bionature. Vol 10, No 1

[97] Muliani, Hirawati .2010.Struktur Mikroanatomi Ren Ayam (Gallus Sp.) karena Pengaruh Pemberian Kunyit Putih (Curcuma Zedoaria). JURNAL ANATOMI FISIOLOGI. Vol 18, No 2

[98] Maryanto, Luthfi Eka, Basyirun, Basyirun, Anis, Samsudin.2018. PENGARUH DIAMETER ROLLER TERHADAP DEBIT POMPA PERISTALTIK. Sainteknol. Vol.16 no.1

[99] Arifulloh, Arifulloh, Oktavianawati, Ika, Adi Winata, I Nyoman.2016. EKSTRAKSI LIKOPEN DARI BUAH TOMAT (LYCOPERSICUM 
ESCULENTUM MILL.) DENGAN BERBAGAI KOMPOSISI PELARUT. Berskala sainstek. Vol.4 no.1

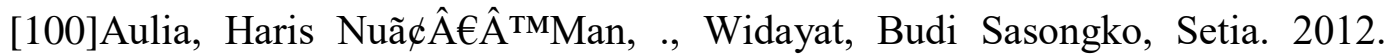
Simulasi Kinetika Reaksi Transesterifikasi Minyak Goreng Bekas Berbantukan Radiasi Ultrasonik. Prosiding Seminar Nasional Sains Dan Teknologi Fakultas Teknik. Vol 1, No 1

[101] Kusnaryo, Radya Purna Wijaya, Ali Altway,. 2008. ANALISA TRANSFER MASSA DISERTAI REAKSI KIMIA PADA ABSORPSI CO2. Teknik Kimia. Vol 2, No 2

[102] Malangngi, Liberty , Sangi, Meiske, Paendong, Jessy . 2012. Penentuan Kandungan Tanin dan Uji Aktivitas Antioksidan Ekstrak Biji Buah Alpukat (Persea americana Mill.). JURNAL MIPA UNSRAT ONLIN. Vol 1, No 1.

[103] Kurniawati, Diani, Rukmi, Mg. Isworo, Lunggani, Arina Tri .2014 .Aktivitas Antimikroba Kombinasi Rebusan Daun Sirih Hijau (Piper Betle) Dan Daun Sirih Merah (Piper Crocatum) Terhadap Candida Albicans. Jurnal Biologi. Vol. 3 No. 1 Januari 2014

[104] Irawan, RM. Bagus,2006. PENGARUH KATALIS TEMBAGA DAN KROM TERHADAP EMISI GAS CARBON MONOKSIDA DAN HIDRO CARBON PADA KENDARAAN MOTOR BENSIN.Vol 4,No 1

[105] Elisabeth, Jenny, Siahaan, D., Simajuntak, D. R. H. 2012. Pemanfaatan Bahan Tumbuhan Sebagai Biokatalisator Dalam Produksi Minyak Sawit Kaya Asam Lemak Omega-3 1) [Using Of Plant Biocatalisator For Omega-3 Pufa -Rich Palm Oil Production]. Jurnal Teknologi Dan Industri Pangan. Vol 13, No 2 (2002)

[106] Soemardi, Eddy, Utami, Pri Iswati, Wakhid, Abdul,2003. UJI ANTI BAKTERI EKSTRAK AIR KUNYIT (Curcuma domestica, Val.) TERHADAP BAKTERI Pseudomonas aeruginosa PADA IKAN GURAMI (Osphronemus gouramy. Lac). Vol 1, No 1

[107] al Hakimi, Nurush Shofi, Hanapi, Ahmand, Fasya, Ahmad Ghanaim 2017.Green Synthesis Senyawa Imina dari Vanillin and Anilina dengan Katalis Alami Air Jeruk Nipis (Citrus aurantifolia). Vol 5, No 4

[108] Hamidy, M Yulis, Malik, Zulkifli, Machyar, Ryan Mutiara. 2012. Gambaran Histopatologi Kerusakan Hati Mencit Yang Diproteksi Dengan Air Rebusan Daun Sirih \{Piper Betle Linn). Jik (Jurnal Ilmu Kedokteran). Vol 3, No 1 (2009)

[109] Hermawanti, Laily. 2015.PENGGABUNGAN ALGORITMA BACKWARD ELIMINATIONDANNAIVE BAYES UNTUK MENDIAGNOSIS PENYAKIT KANKER PAYUDARA. MOMENTUM. Vol 11, No 1

[110] Harlis, Harlis, Wahyuni, Indah.2012. Pengaruh Ekstrak Daun Sirih (Piper betle Linn.) Terhadap Pertumbuhan Bakteri Streptococcus viridans. Biospecies. Vol 1, No 1

[111] Fati, N., Siregar, R. and Sujatmiko, S. (2019) "Addition Of Coleus Amboinicus, L Leaf's Extract In Ration To Percentage Of Carcass, Abdominal Fat, Liver And Heart Broiler”, EKSAKTA: Berkala Ilmiah Bidang MIPA, 20(1), pp. 1-9. doi: 10.24036/eksakta/vol20-iss1/157.

[112] Putri, D., Anika, M. and Wahyuni, W. (2019) "Bioinformatics Study Genes Encoding Enzymes Involved in the Biosynthesis of Carotenoids Line Cassava 
(Manihot esculenta)", EKSAKTA: Berkala Ilmiah Bidang MIPA, 20(1), pp. 10-16. doi: 10.24036/eksakta/vol20-iss1/161.

[113] Suratno, T., Rarasati, N. and Z G. (2019) "Optimization of Genetic Algorithm for Implementation Designing and Modeling in Academic Scheduling", EKSAKTA: Berkala Ilmiah Bidang MIPA, 20(1), pp. 17-24. doi: 10.24036/eksakta/vol20-iss1/166.

[114] Ramalisa, Y., Febriyanti, A. and Multahadah, C. (2019) "Analysis of Non Hierarchical Bomb for Collection of Community Health Degrees in Jambi and Muaro Jambi City", EKSAKTA: Berkala Ilmiah Bidang MIPA, 20(1), pp. 25-34. doi: 10.24036/eksakta/vol20-iss1/167.

[115] Badrulfalah, B., Susanti, D., Joebaedi, K. and Kosasih, R. (2019) "Some Properties of Green's Matrix of Nonlinear Boundary Value Problem of First Order Differential”, EKSAKTA: Berkala Ilmiah Bidang MIPA, 20(1), pp. 4147. doi: 10.24036/eksakta/vol20-iss1/173.

[116] Joebaedi, K., Susanti, D., Warwah, N., Parmikanti, K. and Badrulfalah, B. (2019) "Factors Affecting the Amount of Investment Loans in Commercial Banks with the Application of Linear Regression Analysis Methods", EKSAKTA: Berkala Ilmiah Bidang MIPA, 20(1), pp. 48-54. doi: 10.24036/eksakta/vol20-iss1/172.

[117] Suhaemi, Z., Zulkarnaini, Z., Afrijon, A. and Jefri, P. (2019) "The Study of African Leave (Vernonia amygdalina) in for Improving the Quality of Local Duck Meats of West Sumatera", EKSAKTA: Berkala Ilmiah Bidang MIPA, 20(1), pp. 55-59. doi: 10.24036/eksakta/vol20-iss1/174

[118] Afnuhazi, R. (2019) "Bivariate Analysis on Autism Therapy using Social Skills Training in SLB YPPA Padang", EKSAKTA: Berkala Ilmiah Bidang MIPA, 20(1), pp. 60-76. doi: 10.24036/eksakta/vol20-iss1/175.

[119] Pasaribu, F., Mardia, A. and Sormin, C. (2019) "Ordinal Logistic Regression with an Application to Health Service Quality in Raden Mattaher Jambi Hospital", EKSAKTA: Berkala Ilmiah Bidang MIPA, 20(1), pp. 35-40. doi: 10.24036/eksakta/vol20-iss1/168.

[120] Dinata, M., Fitridawati, F. and Putri, L. (2019) "The Study Trees Potential for Forest in Universitas Lancang Kuning Pekanbaru", EKSAKTA: Berkala Ilmiah Bidang MIPA, 20(1), pp. 77-85. doi: 10.24036/eksakta/vol20iss1/176.

[121] Yanuar, F., Tillah, M. and Devianto, D. (2018) "Modeling of Human Development Index Using Ridge Regression Method", EKSAKTA: Berkala Ilmiah Bidang MIPA, 19(2), pp. 1-11. doi: 10.24036/eksakta/vol19-iss2/134.

[122] Enjelina, W., Mansyurdin, M. and Meideliza, T. (2018) "Analysis of Nepenthes Hybrids in Bukik Taratak West Sumatra by RAPD Technique", EKSAKTA: Berkala Ilmiah Bidang MIPA, 19(2), pp. 12-20. doi: 10.24036/eksakta/vol19-iss2/137.

[123] Syafei, N. (2019) "Events of corrosion phenomena on carbon steel pipes in environment of sea water and ammonia solutions due to the presence of sweet gas", EKSAKTA: Berkala Ilmiah Bidang MIPA, 20(1), pp. 86-99. doi: 10.24036/eksakta/vol20-iss1/178.

[124] Iryani, I., Iswendi, I. And Katrina, I. T. (2017) “Uji Aktivitas Anti Diabetes Mellitus Senyawa Metabolit Sekunder Fraksi Air Dari Beras Ketan Hitam ( 
Oryza Satival. Var Glutinosa) Pada Mencit Putih", Eksakta: Berkala Ilmiah Bidang Mipa, 18(01), Pp. 54-60. Doi: 10.24036/Eksakta/Vol18-Iss01/17.

[125] Rizki Saputra, M. And Sumarmin, R. (2018) "Pengaruh Ekstrak Daun Sirih Merah (Piper Crocatum Ruiz \& Pav.) Terhadap Glukosa Darah Mencit (Mus Musculus L.) Jantan Yang Diinduksi Sukrosa", Eksakta: Berkala Ilmiah Bidang Mipa, 19(1), Pp. 43-55. Doi: 10.24036/Eksakta/Vol19-Iss1/124.

[126] Putri, D., Fifendy, M. And Putri, M. (2018) "Diversitas Bakteri Endofit Pada Daun Muda Dan Tua Tumbuhan Andaleh (Morus Macroura Miq.)”, Eksakta: Berkala Ilmiah Bidang Mipa, 19(1), Pp. 125-130. Doi: 10.24036/Eksakta/Vol19-Iss1/122.

[127] Sari A. (2017). "Potensi Antioksidan Alami Pada Ekstrak Daun Jamblang (Syzigium Cumini L)" Eksakta: Berkala Ilmiah Bidang Mipa, 18(02), Pp.107-112. Doi: 10.24036/Eksakta/Vol18-Iss02/61

[128] Sofyanita S, Octaria Z,. (2018). "Fenthion Compound Degradation In The Pesticide Bayleton 500 Ec In Sonolysis, Ozonolysis And Sonozolysis With Addition Of Tio2-Anatase", Eksakta: Berkala Ilmiah Bidang Mipa, 19(2), Pp 70-79. Doi 10.24036/Eksakta/Vol19-Iss2/153

[129] Vauzia, V. and Gusmira, E. (2018) "The Response of Jabon Seeds

Germination (Anthocephalus cadamba (Roxb.)Miq.) against the Duration of Combustion and Illumination", EKSAKTA: Berkala Ilmiah Bidang MIPA, 19(2), pp. 80-87. doi: 10.24036/eksakta/vol19-iss2/154.

[130] Tuti Tutuarima. (2017)."Sifat Fisik Dan Sifat Kimia Marmalade Jeruk Kalamansi (Citrus Microcarpa): Kajian Kosentrasi Pektin Dan Sukrosa", Eksakta: Berkala Ilmiah Bidang Mipa, 18(02), Pp 164-172. Doi/10.24036/Eksakta/Vol18-Iss02/73

[131] Syafei, Nendi Suhendi.(2017). "Analisa Fenomena Korosi Pelat Pipa Baja Karbon Api 51-X65 Dalam Larutan 250 Ml Asam Aseta Dan $4750 \mathrm{Ml}$ Aquades Pada Kondisi Gas Co2 Dan H2s Jenuh Pada Suhu Ruang", Eksakta: Berkala Ilmiah Bidang Mipa,18(02) Pp,113-120. Doi: 10.24036/Eksakta/Vol18-Iss02/63

[132] Dinata, M. and Soehardi, F. (2018) "Factor Analysis of Physics Chemistry Waters that Affects Damage Safety Cliff on the Outskirts of River Siak", EKSAKTA: Berkala Ilmiah Bidang MIPA, 19(2), pp. 46-49. doi: 10.24036/eksakta/vol19-iss2/143.

[133] Rizki Saputra, M. and Sumarmin, R. (2018) "PENGARUH EKSTRAK DAUN SIRIH MERAH (Piper crocatum Ruiz \& Pav.) TERHADAP GLUKOSA DARAH MENCIT (Mus musculus L.) JANTAN YANG DIINDUKSI SUKROSA", EKSAKTA: Berkala Ilmiah Bidang MIPA, 19(1), pp. 43-55. doi: 10.24036/eksakta/vol19-iss1/124.

[134] Zainul, R. and Wardani, S. (2019) "The Hydrogen Generator Performance of Sandwich Designed 4/4 Al-Cu Plates", EKSAKTA: Berkala Ilmiah Bidang MIPA, 20(1), pp. 100-104. doi: 10.24036/eksakta/vol20-iss1/177.

[135] Mulia M. (2017). "Isolasi Kumarin Dari Kulit Buah Limau Sundai (Citrus Nobilis Lour)", Eksakta: Berkala Ilmiah Bidang Mipa,18(02) Pp.137-45. Doi: 10.24036/Eksakta/Vol18-Iss02/70

[136] Yanuar, F., Tillah, M. and Devianto, D. (2018) "Modeling of Human Development Index Using Ridge Regression Method", EKSAKTA: Berkala Ilmiah Bidang MIPA, 19(2), pp. 1-11. doi: 10.24036/eksakta/vol19-iss2/134. 
[137] Horiza, H., Azhar, M. and Efendi, J. (2017) "EKSTRAKSI DAN KARAKTERISASI INULIN DARI UMBI DAHLIA (Dahlia sp.L) SEGAR DAN DISIMPAN", EKSAKTA: Berkala Ilmiah Bidang MIPA, 18(01), pp. 31-39. doi: 10.24036/eksakta/vol18-iss01/14.

[138] Ramli, R., Jonuarti, R. and Hartono, A. (2017) "ANALISIS STRUKTUR NANO DARI LAPISAN TIPIS COBALT FERRITE YANG DIPREPARASI DENGAN METODE SPUTTERING", EKSAKTA: Berkala Ilmiah Bidang MIPA, 18(01), pp. 46-53. doi: 10.24036/eksakta/vol18-iss01/16.

[139] Ningsih Sk.(2017)."Sintesis Dan Karakterisasi Nanopartikel Zno Doped $\mathrm{Cu} 2+$ Melalui Metoda Sol Gel”, Eksakta:Berkala Bidang Ilmiah Mipa, 18(02), Pp39-41. Doi:10.24036/Eksakta/Vol18-Iss02/51

[140] Parbuntari, H., Prestica, Y., Gunawan, R., Nurman, M. and Adella, F. (2018) "Preliminary Phytochemical Screening (Qualitative Analysis) of Cacao Leaves (Theobroma cacao L.)", EKSAKTA: Berkala Ilmiah Bidang MIPA, 19(2), pp. 40-45. doi: 10.24036/eksakta/vol19-iss2/142.

[141] Hidayani, T. (2018) "GRAFTING POLIPROPILENA DENGAN MALEAT ANHIDRIDA SEBAGAI PENGIKAT SILANG DENGAN INISIATOR BENZOIL PEROKSIDA", EKSAKTA: Berkala Ilmiah Bidang MIPA, 19(1), pp. 56-62. doi: 10.24036/eksakta/vol19-iss1/127.

[142] Handayani, D.(2017) "KARAKTERISTIK CENDAWAN DARK SEPTATE ENDOPHYTE (DSE) PADA AKAR TANAMAN JAGUNG DAN PADI”, EKSAKTA: Berkala Ilmiah Bidang MIPA, 18(01), pp. 61-68. doi: 10.24036/eksakta/vol18-iss01/20.

[143] Samah, S. (2017) "KARAKTERISASI PLASTIK BIODEGRADABEL DARI LDPE-g-MA DAN PATI TANDAN KOSONG SAWIT”, EKSAKTA: Berkala Ilmiah Bidang MIPA, 18(02), pp. 30-38. doi: 10.24036/eksakta/vol18-iss02/48.

[144] Putri, D., Fifendy, M. And Putri, M. (2018) "Diversitas Bakteri Endofit Pada Daun Muda Dan Tua Tumbuhan Andaleh (Morus Macroura Miq)", Eksakta: Berkala Ilmiah Bidang Mipa, 19(1), Pp. 125-130. Doi: 10.24036/Eksakta/Vol19-Iss/122

[145] Prihatini, R. (2017) "PEMANFAATAN AIR KELAPA UNTUK MENINGKATKAN PERTUMBUHAN AKAR STEK TUNAS AKSILAR Andrographis paniculata Nees", EKSAKTA: Berkala Ilmiah Bidang MIPA, 18(02), pp. 62-68. doi: 10.24036/eksakta/vol18-iss02/54.

[146] Saiya, A. (2017) "ANALISIS RESIDU KLORPIRIFOS DALAM SAYURAN KUBIS DENGAN METODE HPLC DI BEBERAPA PASAR TRADISIONAL DI SULAWESI UTARA", EKSAKTA: Berkala Ilmiah Bidang MIPA, 18(02), pp. 77-85. doi: 10.24036/eksakta/vol18-iss02/57.

[147] Zainul, R. and Wardani, S. (2019) "The Hydrogen Generator Performance of Sandwich Designed 4/4 Al-Cu Plates", EKSAKTA: Berkala Ilmiah Bidang MIPA, 20(1), pp. 100-104. doi: 10.24036/eksakta/vol20-iss1/177.

[148] Advinda, L. (2018) "PERTUMBUHAN STEK HORIZONTAL BATANG JARAK PAGAR (Jatropha curcas L.) YANG DIINTRODUKSI DENGAN PSEUDOMONAD FLUORESEN", EKSAKTA: Berkala Ilmiah Bidang MIPA, 19(1), pp. 68-75. doi: 10.24036/eksakta/vol19-iss1/129.

[149] Sari, A. (2017) "POTENSI ANTIOKSIDAN ALAMI PADA EKSTRAK DAUN JAMBLANG (Syzigium cumini (L.) Skeels)”, EKSAKTA: Berkala 
Ilmiah Bidang MIPA, 18(02), pp. 107-112. doi: 10.24036/eksakta/vol18iss02/61.

[150] Zaki utama,Sri raharjo.2006.Formulasi Untuk Memperbaiki Flavor Bubur Buah Alpukat (Persea Americana Mill) Hasil Restrukturisasi. Vol. 26, No. 2 